\title{
An Updated Insight into Learning Approach of Government Sector Dental Students in Balochistan
}

${ }^{1}$ Nabiha Farasat Khan, ${ }^{1}$ Muhammad Saeed, ${ }^{2}$ Ayesha Ayub, ${ }^{3}$ Arshad Kamal Butt

${ }^{1}$ Department of Oral Pathology, Dental Section, Bolan Medical College, Quetta

${ }^{2}$ Health Professional Education and Research Department, Faisalabad Medical University, Faisalabad

${ }^{3}$ Consultant Gastroenterologist, Chughtai Medical Center, DHA, Lahore

\begin{abstract}
Introduction: Learning approach is impacted by character attributes, domain of study, assignments assigned and requirements of medical/dental program. This helps in acquiring cognition through surface and deep learning that influences the amount and standard of learner's acquisition of knowledge.

Aims \& Objectives: The objective of this work was to appraise Learning Approach (Deep or Surface Learning) of dental students at a public sector medical college.

Place and duration of study: Bolan Medical College, Quetta, June-November 2016.

Material \& Methods: After ethical approval, a descriptive observational Census was conducted using RLS tool on 85 BDS (Bachelors of Dental Surgery) students at Bolan Medical College, Quetta. Data was collected on 14 RLS Likert scale variables and analyzed with SPSS version 20.

Results: Eighty-five students participated in study; the response rate was $89.4 \%$. Females constituted $72 \%$ of the participants with a mean composite RLS score of $64.26 \pm 12.46$. Highest mean score was noted for variable 6 (aware of learning task $6.07 \pm 1.46$ ) with $85 \%$ reporting a positive attitude, followed by $71 \%$ on variable 14 (self-assess $5.36+$ 1.95 ), $68 \%$ on variable 12 (use capacity to reflect $5.24 \pm 1.66$ ) and variable 8 (ponder for learning 5.24 \pm 1.59 ). Sixtyseven percent students were able to eliminate study related negative feelings. No statistically significant differences were found between genders and four academic years on all 14 items.

Conclusion: BDS students demonstrated deep learning behavior through mitigating their negative thinking, memorizing learned material, self-assessment of their work and clarifying concepts by making association among themes to better understand the acquired knowledge and impression about subjects.
\end{abstract}

Key words: Dental students, deep learners, learning approaches, learning styles.

\section{INTRODUCTION}

$\mathrm{T}_{\mathrm{h}}$ he overarching goal of higher education is to prepare medical graduates as life-long and selfdirected learners. ${ }^{1}$ Learning and acquisition of knowledge is influenced, amongst other factors, by approach to study. Different researches present different views about learning approaches. Some researchers believe that characteristics of nature, environment of study, students relation, their surrounding and assignments can influence on studying and memorization. ${ }^{2,3}$ While others believe that students study according to the requisite of their training/specialized degree, coaching and learning habitat to the expectance of their community. On the other hand, Marton and Saljo identified two levels of processing i.e. surface and deep, as approaches to learning that express self-developed competencies which were enhanced through reflective work, PBL, small group discussions etc. ${ }^{4,5}$ Intrinsically motivated students have positive emotions about their studies that assist in learning to achieve better academic results. ${ }^{1}$ Medical educationists affirm utilization of surface and deep learning strategies by students. ${ }^{4}$ They classify extrinsically motivated students, who learn through rote learning by memorizing course materials due to the fear of failure as surface learners. On the contrary, intrinsically motivated students monitor their learning to understand as deep learners. ${ }^{6}$

Approaches to learning adopted by students provide actual judgment tool for student's learning and stimulate reflective work through regulating selfdirected learning. Thus, it appears to be a critical calculate in deciding both the amount and attribute of their studying assist in making a difference to instructors to talk about students studying behavior and will influence information of teaching environment. $^{5,7}$ It also provides an attainable appraisal device that assist in studying and memorization that motivates reflective writing by 
encouraging students to monitor and manage their study. The objective of this study is to check the learning approach of all the BDS students in a government owned medical college.

\section{MATERIAL AND METHODS}

Ethical approval for the study was obtained from Bolan Medical College, Quetta, (Letter No. Admin/BMC/2016/2416/18).

Study Desion: An exploratory cross-sectional open (uacriess (c) (1)

Study Population (Inclusion Criteria): First to final year dental students.

Exclusion Criteria: House Officers and Postgraduate residents.

Study Duration: June -November 2016.

Study Tool: Pre validated RLS questionnaire designed by Dejano $\mathrm{TS}^{8,9}$ that has a total of 14 components recorded on a seven-point Likert scale from 1 to 7 with never $=1,2=$ rarely, $3=$ sometimes, 4=undecided, 5=frequently, 6=mostly and $7=$ always. A score of 4 was considered neutral with scores between 1 to 3 as a negative response and scores 5 or above were considered a positive and favorable opinion. Total score on this instrument ranges from 14 to 98.A composite score was calculated for each participant by adding the individual scores of all 14 items.

Validity of Instrument: The Questionnaire was evaluated for face, content and construct validity by two medical education experts in a pilot study conducted on 20 third year BDS students who were excluded from the final study. Ninety-five BDS students were recruited for study after informed consent. Data of 10 participants was found missing/incomplete and hence these were excluded from the final study which reported results of 85 subjects.

\section{Statistical Analysis:}

Data was analyzed using IBM Statistical Package for Social Sciences IBM SPSS 21. Frequency/percentages were reported for qualitative values. RLS questionnaire item scores were reported as Mean \pm SD. Normality assumption of data was evaluated with Kolmogorov-Smirnov test with Lilliefors Correction. Interclass comparison of scores based on professional year as grouping variable was done with Kruskal Wallis (KW) Test since data for all 14 variables was found to be nonnormal. Gender based comparison of scores was achieved with independent sample t-test. For all analyses a $\mathrm{p}$ value $\leq 0.05$ was considered significant.

\section{RESULTS}

Eighty-five out of 95 dental students returned the completed questionnaire with a response rate of $89.4 \%$. Male to female ratio was 1:2.6 (23 males versus 62 females). Seventy-six percent $(n=65 / 85)$ respondents were more than twenty years old. Participants enrolled in $1^{\text {st }}$ to $4^{\text {th }}$ year were 21,16 , 21 and 27 respectively.

Highest score was noted for item number 6 "Awareness of learning task" with mean $6.07 \pm 1.46$ followed by item number 14 "Self-assess" with mean of $5.37 \pm 1.95$. Items number 8 and 12 "Ponder for learning" with mean of $5.24 \pm 1.59$ and "Use capacity to reflect" with mean of $5.24 \pm 1.66$ respectively achieved the third highest score. Table1 presents the details of all 14 items and their scores. In Table- 2 mean score of all variables across the 4 academic years is displayed. Highest scores were achieved by $2^{\text {nd }}$ year BDS students on items number $1,5,8-11$, followed by $3^{\text {rd }}$ year students who achieved highest scores on item 2-4, 6 and 7 and finally $4^{\text {th }}$ year students had the highest mean scores for items 12-14.

Analysis of gender-based distribution of RLS scores presented in Table-3 indicated higher scores by females on 8 items with males achieving higher scores on remaining 6 items. Composite scores for males and females were $62.78 \pm 9.99$ and $64.26 \pm$ 12.46 respectively. However, differences in scores between males and females failed to achieve statistical significance either on individual items or on composite scores.

Data on analysis of scores on all 14 items appears in Table-4. Between groups comparisons of scores using $\mathrm{KW}$ test presented in Fig-1 indicated that statistically significant differences between the four academic years existed on items one, six, seven and eleven.

\begin{tabular}{|l|c|c|c|c|}
\hline Variables & Min. & Max. & Mean & $\underline{\mathbf{} S . D}$ \\
\hline Carefully plan task & 1.00 & 7.00 & 4.80 & 1.71 \\
\hline Discussion with colleagues & 1.00 & 7.00 & 4.62 & 1.85 \\
\hline Review study & 1.00 & 7.00 & 4.38 & 1.73 \\
\hline integration & 1.00 & 7.00 & 3.95 & 1.73 \\
\hline Process mentally & 1.00 & 7.00 & 4.92 & 1.75 \\
\hline Aware of learning task & 2.00 & 7.00 & 6.07 & 1.46 \\
\hline Develop interrelation & 1.00 & 7.00 & 4.82 & 1.80 \\
\hline Ponder for learning & 2.00 & 7.00 & 5.24 & 1.59 \\
\hline Change myself for study & 1.00 & 7.00 & 4.74 & 2.00 \\
\hline Reflection on study & 1.00 & 7.00 & 4.62 & 1.88 \\
\hline Make summary & 1.00 & 7.00 & 4.72 & 1.91 \\
\hline Use capacity to reflect & 1.00 & 7.00 & 5.24 & 1.66 \\
\hline Remove negativity & 1.00 & 7.00 & 5.14 & 1.94 \\
\hline Self-assess & 1.00 & 7.00 & 5.36 & 1.95 \\
\hline
\end{tabular}

Table-1: Descriptive statistics of student's responses to the Reflection-in-Learning Scale questionnaire 


\begin{tabular}{|c|c|c|c|c|}
\hline \multicolumn{2}{|c|}{ 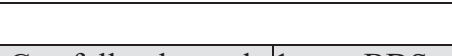 } & $\mathrm{N}$ & Mean & Std. Dev \\
\hline \multirow[t]{4}{*}{ Carefully plan task } & 1 year BDS & 21 & 3.90 & 1.37 \\
\hline & 2 year BDS & 16 & 5.93 & 1.52 \\
\hline & 3 year BDS & 21 & 4.61 & 1.56 \\
\hline & 4 year BDS & 27 & 4.96 & 1.82 \\
\hline \multirow{4}{*}{$\begin{array}{l}\text { Discussion with } \\
\text { colleagues }\end{array}$} & 1 year BDS & 21 & 4.14 & 1.80 \\
\hline & 2 year BDS & 16 & 5.12 & 1.40 \\
\hline & 3 year BDS & 21 & 5.28 & 1.67 \\
\hline & 4 year BDS & 27 & 4.18 & 2.09 \\
\hline \multirow[t]{4}{*}{ Review study } & 1 year BDS & 21 & 4.61 & 1.65 \\
\hline & 2 year BDS & 16 & 4.31 & 1.66 \\
\hline & 3 year BDS & 21 & 5.04 & 1.90 \\
\hline & 4 year BDS & 27 & 3.74 & 1.53 \\
\hline \multirow[t]{4}{*}{ Integration } & 1 year BDS & 21 & 3.90 & 1.57 \\
\hline & 2 year BDS & 16 & 3.81 & 1.97 \\
\hline & 3 year BDS & 21 & 4.14 & 2.10 \\
\hline & 4 year BDS & 27 & 3.92 & 1.46 \\
\hline \multirow[t]{4}{*}{ Process mentally } & 1 year BDS & 21 & 4.61 & 1.88 \\
\hline & 2 year BDS & 16 & 5.43 & 1.45 \\
\hline & 3 year BDS & 21 & 5.14 & 1.52 \\
\hline & 4 year BDS & 27 & 4.70 & 1.95 \\
\hline \multirow{4}{*}{$\begin{array}{l}\text { Aware of learning } \\
\text { task }\end{array}$} & 1 year BDS & 21 & 5.19 & 1.66 \\
\hline & 2 year BDS & 16 & 6.00 & 1.82 \\
\hline & 3 year BDS & 21 & 6.61 & 0.80 \\
\hline & 4 year BDS & 27 & 6.37 & 1.18 \\
\hline \multirow{4}{*}{$\begin{array}{l}\text { Develop } \\
\text { interrelation }\end{array}$} & 1 year BDS & 21 & 4.14 & 1.71 \\
\hline & 2 year BDS & 16 & 4.37 & 1.85 \\
\hline & 3 year BDS & 21 & 5.80 & 1.60 \\
\hline & 4 year BDS & 27 & 4.77 & 1.64 \\
\hline \multirow[t]{4}{*}{ Ponder for learning } & 1 year BDS & 21 & 4.85 & 1.49 \\
\hline & 2 year BDS & 16 & 5.93 & 1.56 \\
\hline & 3 year BDS & 21 & 5.38 & 1.74 \\
\hline & 4 year BDS & 27 & 5.03 & 1.50 \\
\hline \multirow{4}{*}{$\begin{array}{l}\text { Change myself for } \\
\text { study }\end{array}$} & 1 year BDS & 21 & 4.57 & 1.96 \\
\hline & 2 year BDS & 16 & 5.18 & 1.72 \\
\hline & 3 year BDS & 21 & 4.85 & 1.82 \\
\hline & 4 year BDS & 27 & 4.51 & 2.34 \\
\hline \multirow[t]{4}{*}{ Reflection on study } & 1 year BDS & 21 & 4.76 & 1.86 \\
\hline & 2 year BDS & 16 & 5.00 & 1.09 \\
\hline & 3 year BDS & 21 & 4.85 & 2.17 \\
\hline & 4 year BDS & 27 & 4.29 & 2.05 \\
\hline \multirow[t]{4}{*}{ Make summary } & 1 year BDS & 21 & 4.09 & 1.72 \\
\hline & 2 year BDS & 16 & 4.87 & 1.89 \\
\hline & 3 year BDS & 21 & 5.80 & 1.36 \\
\hline & 4 year BDS & 27 & 4.29 & 2.14 \\
\hline \multirow{4}{*}{$\begin{array}{l}\text { Use capacity to } \\
\text { reflect }\end{array}$} & 1 year BDS & 21 & 4.61 & 1.62 \\
\hline & 2 year BDS & 16 & 5.18 & 1.64 \\
\hline & 3 year BDS & 21 & 5.42 & 1.69 \\
\hline & 4 year BDS & 27 & 5.62 & 1.64 \\
\hline \multirow[t]{4}{*}{ Remove negativity } & 1 year BDS & 21 & 4.80 & 2.20 \\
\hline & 2 year BDS & 16 & 5.12 & 1.40 \\
\hline & 3 year BDS & 21 & 4.85 & 2.17 \\
\hline & 4 year BDS & 27 & 5.62 & 1.82 \\
\hline \multirow[t]{4}{*}{ Self-assess } & 1 year BDS & 20 & 5.48 & 1.40 \\
\hline & 2 year BDS & 16 & 5.37 & 1.99 \\
\hline & 3 year BDS & 21 & 4.90 & 2.50 \\
\hline & 4 year BDS & 27 & 5.62 & 1.86 \\
\hline
\end{tabular}

Table-2: Variables Mean scores across 4 academic groups

\begin{tabular}{|c|c|c|c|c|}
\hline & gender & $\mathbf{N}$ & Mean & \pm S.D \\
\hline \multirow{2}{*}{$\begin{array}{l}\text { 1. Develop } \\
\text { interrelation }\end{array}$} & male & 23 & 4.52 & 1.80 \\
\hline & female & 62 & 4.93 & 1.68 \\
\hline \multirow[t]{2}{*}{ 2. Carefully plan task } & male & 23 & 4.60 & 1.72 \\
\hline & female & 62 & 4.65 & 1.91 \\
\hline \multirow{2}{*}{$\begin{array}{l}\text { 3. Discussion with } \\
\text { colleagues }\end{array}$} & male & 23 & 4.04 & 1.49 \\
\hline & female & 62 & 4.47 & 1.79 \\
\hline \multirow[t]{2}{*}{ 4. Review study } & male & 23 & 4.17 & 1.64 \\
\hline & female & 62 & 3.81 & 1.74 \\
\hline \multirow[t]{2}{*}{ 5. Integration } & male & 23 & 5.21 & 1.65 \\
\hline & female & 62 & 4.85 & 1.78 \\
\hline \multirow[t]{2}{*}{ 6. Process mentally } & male & 23 & 5.82 & 1.69 \\
\hline & female & 62 & 6.14 & 1.37 \\
\hline \multirow{2}{*}{$\begin{array}{l}\text { 7. Aware of learning } \\
\text { task }\end{array}$} & male & 23 & 4.56 & 1.59 \\
\hline & female & 62 & 4.85 & 1.82 \\
\hline \multirow[t]{2}{*}{ 8. Ponder for learning } & male & 23 & 5.30 & 1.49 \\
\hline & female & 62 & 5.19 & 1.64 \\
\hline \multirow{2}{*}{$\begin{array}{l}\text { 9. Change myself for } \\
\text { study }\end{array}$} & male & 23 & 4.56 & 1.85 \\
\hline & female & 62 & 4.83 & 2.06 \\
\hline \multirow[t]{2}{*}{ 10. Reflection on study } & male & 23 & 4.82 & 1.55 \\
\hline & female & 62 & 4.59 & 1.99 \\
\hline \multirow[t]{2}{*}{ 11. Make summary } & male & 23 & 4.52 & 1.67 \\
\hline & female & 62 & 4.77 & 2.00 \\
\hline \multirow{2}{*}{$\begin{array}{l}\text { 12. Use capacity to } \\
\text { reflect }\end{array}$} & male & 23 & 4.82 & 1.64 \\
\hline & female & 62 & 5.44 & 1.64 \\
\hline \multirow[t]{2}{*}{ 13. Remove negativity } & male & 23 & 5.17 & 1.69 \\
\hline & female & 62 & 5.09 & 2.04 \\
\hline \multirow[t]{2}{*}{ 14. Self assess } & male & 23 & 5.17 & 1.74 \\
\hline & female & 61 & 5.42 & 2.04 \\
\hline
\end{tabular}

Table-3: Descriptive statistics on RLS scores based on gender

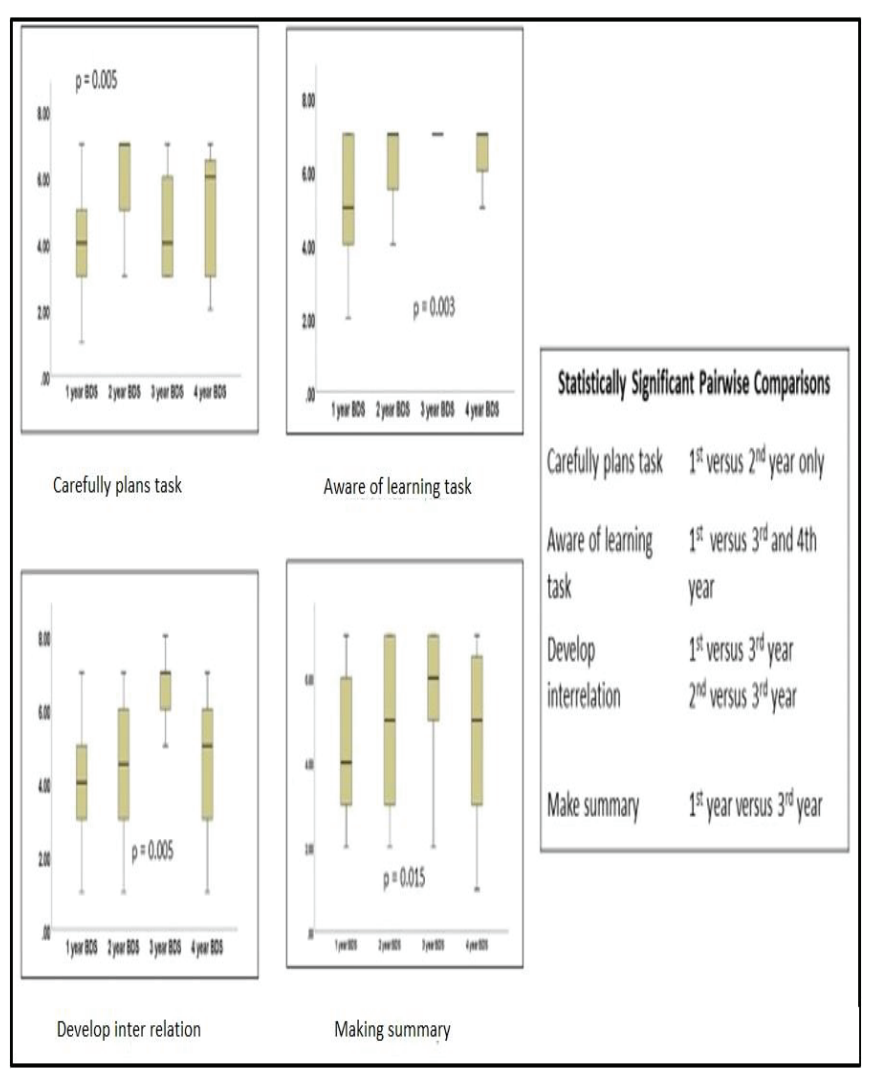

Fig-1: Kruskal Wallis ANOVA for significant differences 


\section{DISCUSSION}

Baluchistan, largest province of country, is a relatively economically underprivileged and under developed area of Pakistan. Undergraduate students enrolled in dentistry in different public and private sector colleges in Baluchistan have different societal norms, backgrounds, tribal contexts and have experienced divergent modes of coaching and learning in their respective institutes with different studying styles. ${ }^{9}$ These elements have a profound influence on their cognitive behavior and learning level whether they are surface or deep learners. In addition, teaching strategies also play an important role in students' learning. Students of innovative teaching and learning methodologies (Problem Based Learning, Small Group Discussions, Tutorial Based Learning) are considered deep learners who actively set their learning goals, acquire knowledge by highlighting/underlining and rereading, selfexplain, summarize, the keyword mnemonic and employ imagery use for text learning preparing them as self-directed learners whereas traditional teaching methodologies suppress students' learning abilities. $^{10,11}$

Research throughout world assessed learning approach of medical students ${ }^{12,13}$ while in Pakistan Rehman $\mathrm{R}^{14}$ and Gull $\mathrm{A}^{15}$ investigated the same parameters in our medical students. However, no work has been done in our country to assess learning approach of dental students. So this study was done to evaluate the learning approach of dental students through RLS questionnaire.

In current study, students scored highest on item number 6 "Awareness of learning task" with mean $6.07 \pm 1.46$ followed by item 14 "Self-assess" with mean of $5.37 \pm 1.95$. Items number 8 and 12 "Ponder for learning" with mean of $5.24 \pm 1.59$ and "Use capacity to reflect" with mean of $5.24 \pm 1.66$ respectively achieved the third highest score.

Working on item 6 "Aware of learning tasks" students were able to identify their areas of weakness and strengths when they were aware of their learning tasks. They focused on their target areas to overcome their weaknesses and to strengthen their good areas. ${ }^{1}$ Students attained pronounced progress when they were cognizant of their learning needs, achievable goals and objectives. Surprisingly finest teaching methodologies didn't affect those students who were unaware of their learning needs. ${ }^{1}$

On the other hand, students acting on self-evaluation judged the quality of their work in order to improve themselves. ${ }^{16}$ Self-assessment not only strengthens studying abilities but it also assists in learner's life- long learning. It helps them to be a deep learner. ${ }^{16}$ Results of a meta-analysis confirmed effects of selfassessment; that it boosts motivation and increases interest in the subject/topic resulting good academic records. ${ }^{17}$

Learners of our research performed good on item number 8 "Ponder to learn." They demonstrated keenness to learn and thought about their learned material in order to clear the concepts regarding what they had learnt. Whereas working on item 12 "reflection" students memorized and wrote the studied material in their own words that helped in understanding the meaning of their learned material. They read, reflected, checked and re-reflected which put the material into their long-term memory.

When comparing items and professional years, Devil and associates during their research work on 153 medical students found high achievers are energetic, strictly work out on their study assignments; intellectually prepare what they know and their learning needs. They have the ability of good decision-making and they self-monitor themselves to accomplish target. ${ }^{14}$ Similarly in current study students of $2^{\text {nd }}$ year BDS got highest mean on item number 1 and 8 (Carefully Planned and Ponder to Learn with $5.93 \pm 1.52$ and 1.56 respectively), second highest number was taken on item number 5 (Process Mentally with 5.43 \pm ) while item number 9 (Change My-self for Study) and ten (Reflect Systematically) were $3^{\text {rd }}$ and $4^{\text {th }}$ in number (5.18 1.72 and $5.00 \pm 1.09$ respectively)

Students of $3^{\text {rd }}$ year achieved highest mean on item number 6 (Aware of Learning Task with 6.61士 $0.80), 2^{\text {nd }}$ highest number in item number 7 and 11 (Interrelate Topics 5.80土1.60 and Make Summary $5.80 \pm 1.36$ respectively) and $3^{\text {rd }}$ number at item number 2 (Discuss with Colleagues with $5.04 \pm 1.90)$. Students of $3^{\text {rd }}$ year BDS scoring (Mean \pm SD $5.80 \pm 1.60$ on item number 7 is correlated with the results of Sobral et al. Sobral DT observed stronger correlation coefficient at the endof-term for item $7 .{ }^{9}$ In order to create more complete conceptions about themes, students of $3^{\text {rd }}$ year interrelated topics. This procedure made easy memorization as students worked on Reflection-inaction at this time while thoughts and action worked together. As we interpret, those things can be better learnt and saved in long-term memory which we understand thoroughly and repeat frequently. The other second most common item in current study was item 11 selected by the students of $3^{\text {rd }}$ year. For better memorization respondents of Sobral DT also summarized their learned material. ${ }^{9}$ It was observed that the study population of Sobral also performed variable "eleven" similar to our students 
continuously. ${ }^{9}$ Students summarizing their learned material, comparing experiences; explained the procedures/problems and its solutions during their studies were working on third stage of reflection "Reflection-on-Action". A refinement in their selfawareness was noted which helped in personal and professional development.

Final year students got highest mean at item number 5 (Processed Mentally with $6.37 \pm 1.18$ ) whereas item number 12,13 and 14 received equal mean from the participants of $4^{\text {th }}$ year (Reflection, Remove Negative Feelings and Self-Assessed with $5.62 \pm 164,5.62 \pm 1.82$ and $5.62 \pm 1.86$ respectively). Experience, clinical rotations, discussion with peers, senior doctors and resident are the elements that aided in the deep learning of $4^{\text {th }}$ year BDS students of current study. Devi V reported in his research about those tasks which were also performed by the students of pharmacology more often. ${ }^{18}$ In item number 13 when students removed their negative thinking, they focused on their goals and worked to achieve aims and objective easily. Students detaching and neutralizing their bad thoughts were able to accomplish their target. Working on item number "thirteen", they were strong enough to execute plans. Studies demonstrated that the students with negativism and lack of confidence regarding their studies, demonstrated lack of interest in learning. These students were unaware of their target and did not have a goal oriented performance. ${ }^{18,} 19$ Problems can be solved easily when someone is positive in his/her thoughts. Student's ideas and response serve in studying areas as well as assist in assuming additional essential expertise like innovative and analytical reasoning. ${ }^{20,21}$ Similarly, results of another study exhibited that the problem based learning improves deep learning. ${ }^{22}$ These students were positive thinkers that helped in their struggle to achieve their target. Likewise, students with negative feelings about their study, aim and/or study related problems were unable to pay attention to their aims and objectives and will never attain their goals in life. ${ }^{17}$ Problems can be solved easily when someone is positive in his/her thoughts. Learner's thoughts and emotions assist in learning areas and help in assuming other essential skills like creative and critical thinking. ${ }^{20,21}$ The difference of pre-clerk and clerk ship experience in students of $4^{\text {th }}$ year is that they acquire feedback, backup and more time from their seniors, postgraduate trainees and consultants that enables them to reflect on situations, conditions, problems and challenges they face during their rotations in different clinics which further accelerates their reflective thinking. Self-assessment means analysis of thinking processes, an essential part of reflection. Students working on selfreporting were able to judge their deficiencies and shortcomings in study. Self-assessment lead to increased students interest which successfully heightens studying potential. ${ }^{22}$ Another major reason of high reflective abilities of senior classes are the stages of Reflection-in-Action; where they are currently learning and practicing side by side, whereas pre-clerks are at the stage of Reflectionbefore Action as they reflect what they know from their past knowledge. The satisfactory results of respondents of fourth professional year indicated that these students are one-step ahead to resolute initial learning activities as compared to first and second year students. Moreover, $4^{\text {th }}$ year students were more self-monitored in their study as compared to the junior's category. Reflective level also relies on student's self-confidence and balanced diagnostic approach. Correspondingly the quantity of reflective work was excellent as students of higher professional years of dentistry in another research work by Amal SM (2010). ${ }^{1}$

Paired wise comparisons demonstrated statistically significant correlation $(\mathrm{p}=0.005)$ between $1^{\text {st }}$ and $2^{\text {nd }}$ year students in item number ONE "Carefully plan tasks". Like-wise statistically significant correlation $(\mathrm{p}=0.003)$ was detected in $1^{\text {st }}$ year vs $3^{\text {rd }}$ year and $4^{\text {th }}$ year students at item number SIX "Aware of learning tasks." When we assessed correlation in $1^{\text {st }}$ year vs $3^{\text {rd }}$ year and $2^{\text {nd }}$ vs $3^{\text {rd }}$ year at item number FOUR "Develop interrelation" we noticed statistically significant correlation. On the other hand, item number ELEVEN "Make summary" also demonstrated statistically significant correlation between $1^{\text {st }}$ year vs $3^{\text {rd }}$ year dental students. The results of our study correlated with the results of Sobral DT who detected highly significant correlation $(\mathrm{p}<0.001)$ in all cases. ${ }^{8,9}$

Sobral DT study reflected the behavior of majority of the students working on item number FOUR "Interrelate topics," students making connection in divergent directions of different topics to clear their mind about the learning material making memorization easy. Interrelating topics helps students analyze their observations, working on second stage of Reflection "Reflection-duringaction" where thinking is analyzed and responded to critically. Scientists claimed that objects/subjects can be memorized in long term memory when revised repeatedly. ${ }^{23}$ Results of Paired wise comparisons of current study detected correlation in $1^{\text {st }}$ year vs $3^{\text {rd }}$ year and $2^{\text {nd }}$ vs $3^{\text {rd }}$ year at item number FOUR "Develop interrelation" we noticed statistically significant correlation $(p=0.005)$. 
Students were adopting organized approach to get high academic grades. Study participants of our research demonstrated to be good reflective learners especially senior students ( $3^{\text {rd }}$ and $4^{\text {th }}$ year). This is because they are utilizing monitoring and deep learning approach and presented themselves as selfregulated learners.

In current study gender, wise comparison demonstrates satisfactory results scored by the girls than boys. Statistical significance scores were observed in items number "six, eight and fourteen. Female predominance in "Learning Tasks, Ponder to learn and Self-Assess their work" was also observed in other researchers work. ${ }^{1,24}$ Girls are prominent in these tasks due to their high will power, persistent struggling quality and maturity proving to be in the lead. ${ }^{25}$ On the other hand, Grant A and Sobral DT both researchers did not find any difference between gender and learning approach in their scientific research work. ${ }^{8,9,11}$

\section{CONCLUSION}

This was the first study conducted in the country as well as provincial level, which assessed Learning Behavior of dental students in a public sector dental institute. Students presented good learning behavior despite of traditional teaching and learning strategies applied in College.

Current study demonstrated deep learning approach of senior students. BDS students were cognizant to learn, anxious to amalgamate, explicit their notions by creating association between topics/subjects, interrelate study material, reflect systematically to memorize, ponder for learning, remove negative feelings during their learning and assess their work critically for betterment of their studies. Additionally working in clinics, interaction with patients, colleague's, seniors and faculty enhanced their experience.

Acknowledgement: authors are thankful to the students of all professional years for their voluntarily participating in this research work.

\section{REFERENCES}

1. Amal M. The reflective process among undergraduate dental students: the impact of age, gender, learning styles, learning approaches and the dental environment The Reflective Process among Undergraduate Dental Students : the Impact of Age , Gender, Learning s. Jpostgr Med Thesis Queen Mary Univ London. 2010; 58(4):270-4.

2. Entwistle NJ, Ramsden P. Understanding student learning [Internet]. Vol. 32, British Journal of
Educational Studies. 1982. 9-25 p.

3. Biggs J, Kember D, Leung DYP. The Revised Two Factor Study Process Questionnaire : R-SPQ-2F The Revised Two Factor Study Process Questionnaire: R-SPQ-2F. Br J Educ Psychol. 2001; 71:133-49.

4. Marton F, Säljö R. on Qualitative Differences in Learning: I-Outcome and Process*. $\mathrm{Br} \mathrm{J}$ Educ Psychol [Internet]. 1976; 46(1):4-11.

5. Jayawardena CK, Hewapathirana TN, Banneheka S, Ariyasinghe S, Ihalagedara D. Association of Learning Approaches With Academic Performance of Sri Lankan First-Year Dental Students. Teach Learn Med. 2013; 25(4):334-41.

6. Noel Entwistle, Velda McCune, PW. Conceptions, styles and approaches within higher education: analytic abstractions and everyday experience. 2001. p. $103-36$

7. Lonka K, Olkinuora E, Mäkinen J. Aspects and prospects of measuring studying and learning in higher education. Educ Psychol Rev. 2004; 16(4):301-23.

8. Sobral DT. An appraisal of medical students' reflection-in-learning. Med Educ. 2000; 34(3):182-7.

9. Sobral DT. Medical students' mindset for reflective learning: A revalidation study of the reflection-inlearning scale. Adv Heal Sci Educ. 2005;10(4):303-14.

10. Spencer JA, Jordan RK, Ne T, Spencer JA, Jordan RK. Learner centred approaches in medical education. 1999; 318(7193): 1280-3.

11. Grant A, Kinnersley P, Field M. Dental students ' reflective habits: is there a relation with their academic achievements? BMC Res Notes.2012;5:153

12. Shah DK, Yadav RL, Sharma D, Yadav PK, Sapkota NK, Jha RK, et al. Learning approach among health sciences students in a medical college in Nepal: a cross-sectional study. Adv Med Educ Pract [Internet]. 2016; 7:137-43.

13. Cebeci S, Dane S, Kaya M, Yigitoglu R. Medical Students' Approaches to Learning and Study Skills. Procedia - Soc Behav Sci [Internet]. 2013; 93:732-6.

14. Rehman R, Ahmed K, Rehan R, Hassan F, Syed F. Learning approaches and performance of medical students. J Pak Med Assoc. 2016; 66(2):198-202.

15. Ambreen, Altaf A, Qamar K, Huda N, Liaqat H. Learning Approaches of Medical Students in a CaseBased Learning Curriculum in Pre- Clinical Years. Pak Armed Forces Med J. 2018; 68(6):1749-54.

16. Kennedy G, Rea JNM, Rea IM. Prompting medical students to self-assess their learning needs during the ageing and health module: a mixed methods study. Med Educ Online [Internet]. 2019; 24(1):1-12.

17. Sitzmann T, Brown KG, Bauer KN. Self-Assessment of Knowledge: A Cognitive Learning or Affective Measure? Acad Manag Leaning Educ. 2010; 9(2):169-91.

18. Devi V, Mandal T, Kodidela S P V. Integrating students' reflection-in-learning and examination performance as a method for providing educational feedback. J Postgr Med,. 2012; 58(4):270-4.

19. Cron WL, Slocum JW, VandeWalle D, Fu Q. The 
role of goal orientation on negative emotions and goal setting when initial performance falls short of one's performance goal. Hum Perform. 2005; 18(1):55-80.

20. Dehghani M, Jafari H, Pakmehr H, Malekzadeh A. Relationship between Students 'Critical Thinking and Self-efficacy Beliefs in Ferdowsi University of Mashhad, Iran. Procedia Soc Behav Sci. 2011; $15: 2952-5$

21. Sayadian S, Lashkarian A. EFL learners ' creative thinking and their achievement emotions. Procedia Soc Behav Sci. 2015; 199:505-9.

22. Abraham RR, Vinod P, Kamath MG, Asha K, Ramnarayan K. Learning approaches of undergraduate medical students to physiology in a non-PBL- and partially PBL-oriented curriculum. AJP Adv Physiol Educ. 2008; 32(1):35-7.

23. Kelley P, Whatson T. Making long-term memories in minutes: a spaced learning pattern from memory research in education.Front Hum Neurosci.2013;7:1-9

24. Chuan-Yuan C, Ying-Tai W, Ming-Hsia H, Jia-Te L. Reflective Learning in Physical Therapy Students: Related Factors and Facilitative Effects of a Short Introduction. Procedia - Soc Behav Sci. 2013; 93:1362-7.

25. Khan NF, Saeed M, Yasmin R, Butt AK, Khan AA. Age and Gender Based Differences in Self-Assessed Reflection in-Learning Scale. J Pakistan Dent Assoc. 2018; 27(03):133-9.

\section{The Authors:}

Dr. Nabiha Farasat Khan, HOD Oral Pathology, Dental Section, Bolan Medical College, Quetta.

Dr. Muhammad Saeed,

Senior Demonstrator,

Oral Pathology Department, Dental Section, Bolan Medical College, Quetta.

Dr. Ayesha Ayub,

Demonstrator,

Health Professional Education and Research

Department,

Faisalabad Medical University, Faisalabad.

Prof. Arshad Kamal Butt,

Consultant Gastroenterologist,

Chaughtai Medical Centre, DHA, Lahore.

\section{Corresponding Author:}

Dr. Nabiha Farasat Khan, HOD Oral Pathology, Dental Section, Bolan Medical College, Quetta.

E-mail: nabihasaeed@hotmail.com 